\title{
Kadar glukosa darah dan tekanan darah pada penduduk pedesaan dan perkotaan di Daerah Istimewa Yogyakarta
}

\author{
Tasmini, ${ }^{*}$ Arta Farmawati, Sunarti, Pramudji Hastuti, Ahmad Hamim Sadewa, Prasetyastuti, Ngadikun \\ Departemen Biokimia, Fakultas Kedokteran, Kesehatan Masyarakat, dan Keperawatan, \\ Universitas Gadjah Mada, Yogyakarta, Indonesia
}

\author{
Submitted: 10 Oktober 2018 Revised: 21 Oktober 2018 Accepted: 7 November 2018
}

\begin{abstract}
ABSTRAK Sebagian besar penduduk di daerah pedesaan bertaraf ekonomi menengah ke bawah, memiliki keterbatasan akses informasi, dan memiliki mata pencaharian berbeda dibanding penduduk kota. Bantar Kulon merupakan daerah pedesaan dan Kronggahan adalah daerah perkotaan di Yogyakarta. Mengingat terjadinya pergeseran pola penyakit dari penyakit menular ke penyakit tidak menular serta adanya pengaruh lingkungan dan gaya hidup terhadap terjadinya penyakit degeneratif, dilakukan pengkajian mengenai faktor risiko sindroma metabolik di dua daerah tersebut. Penelitian ini dilakukan untuk mengetahui apakah ada perbedaan kadar glukosa darah puasa (GDP) dan tekanan darah (TD), serta keluhan/ penyakit utama pada penduduk di daerah pedesaan dan perkotaan. Sebanyak 71 orang dari Bantar Kulon dan 91 orang dari Kronggahan diperiksa kadar GDP-nya menggunakan GCU Multi-Function Monitoring System (EasyTouch ${ }^{\circledR}$ ). Tekanan darah diperiksa dengan sphygmomanometer raksa dan otomatis. Kadar GDP dan TD pada subjek dari kedua lokasi ditampilkan dalam bentuk deskriptif berdasarkan cut-off (GDP: $\geq 100 \mathrm{mg} / \mathrm{dL}$; TD: $\geq$ 140/90 mmHg). Uji t atau Mann Whitney $U$ dilakukan untuk mengetahui perbedaaan nilai variabel antara kedua lokasi. Hasil dinyatakan berbeda bermakna jika $p<0,05$. Data keluhan penyakit utama ditampilkan secara deskriptif. Tidak ada perbedaan kadar GDP antara desa dan kota $(p=0,385)$. Persentase subjek yang memiliki GDP $\geq 100 \mathrm{mg} / \mathrm{dL}$ lebih banyak di desa dibanding di kota (42,3\% vs 26,4\%). Persentase hipertensi lebih tinggi di kota dibanding di desa $(50,5 \%$ vs $33,8 \%)$. Berdasarkan wawancara, keluhan/ penyakit utama terbanyak pada kedua wilayah adalah hipertensi sebanyak 23 orang $(32,4 \%)$ di desa dan 30 orang $(33,0 \%)$ di kota. Kadar GDP di atas normal lebih banyak ditemukan di desa sedangkan hipertensi lebih banyak ditemukan di kota. Keluhan/ penyakit utama di kedua wilayah adalah hipertensi.
\end{abstract}

KATA KUNCI kadar glukosa darah; penyakit metabolik; hipertensi; pedesaan; perkotaan

ABSTRACT Most people living in rural areas are from lower to middle income class, have limited access to information, and have different occupations compared to those in urban areas. In Yogyakarta, Bantar Kulon is a rural area, while Kronggahan is an urban area. Currently, the pattern of disease is shifting from infectious diseases to non-communicable diseases with environment and lifestyle factors as determinants. Thus, it is necessary to study the trends of risk factors for metabolic syndrome in both areas. This study aimed to seek the difference of fasting blood glucose (FBG), blood pressure (BP), and major complaints/illness between rural and urban areas. Seventy one people from Bantar Kulon and 91 people from Kronggahan were examined for FBG levels using GCU Multi-Function Monitoring System (EasyTouch ${ }^{\circledR}$ ). Blood pressures were checked using sphygmomanometer. Levels of $F B G$ and $B P$ were presented as frequencies based on cut-offs (FBG: $\geq 100 \mathrm{mg} / \mathrm{dL} ; B P: \geq 140 / 90 \mathrm{mmHg}$ ). T-test or Mann-Whitney $U$ test were used to analyze the difference of variables between both areas. Results were significantly different if $p<0.05$. Chief complaint ilness data were displayed descriptively. There was no difference in FBG level between rural and urban

\footnotetext{
*Corresponding author: Tasmini

Departemen Biokimia, Fakultas Kedokteran, Kesehatan Masyarakat, dan Keperawatan, Universitas Gadjah Mada, Jl. Farmako, Sekip Utara, Yogyakarta 55281, Indonesia

E-mail: ts_tasmini@yahoo.com
} 
areas $(p=0.385)$. The percentage of subjects with $F B G \geq 100 \mathrm{mg} / \mathrm{dL}$ was higher in Bantar Kulon than in Kronggahan (42.3\% vs 26.4\%). Percentage of hypertension was higher in urban than rural areas (50.5\% vs. 33.8\%). Based on interviews, the chief complaint/ illness in both areas was hypertension. The number of subjects who were diagnosed with hypertension were 23 (32.4\%) and 30 (33.0\%) from Bantar Kulon and Kronggahan respectively. Impaired fasting glucose was more common in rural area while hypertension is more common in urban area. The chief complaint/illness in both regions is hypertension.

KEYWORDS blood glucose; metabolic syndrome; hypertension; rural area; urban area

\section{Pendahuluan}

Prevalensi penyakit metabolik semakin meningkat dari waktu ke waktu seiring bergesernya tren penyakit menular ke tidak menular. Kondisi ini sangat merugikan, baik bagi penderitanya sendiri, masyarakat, maupun negara secara ekonomi. ${ }^{1}$ Secara umum, prevalensi sindrom metabolik di dunia adalah $25,0 \%$ pada orang dewasa dengan peningkatan prevalensi seiring bertambahnya usia. ${ }^{2}$ Di Indonesia, berdasarkan analisis lanjutan dari data Riset Kesehatan Dasar (Riskesdas) 2013, prevalensi sindrom metabolik pada orang dewasa adalah sekitar 23,0\%, 26,6\% pada wanita, dan $18,3 \%$ pada laki-laki. ${ }^{3}$ Sindrom metabolik diderita oleh sekitar 5,0\% orang dengan berat badan normal, $22,0 \%$ pada orang dengan berat badan lebih dan $60,0 \%$ pada mereka yang obesitas.

Menurut The National Cholesterol Education Program Adult Treatment Panel (NCEP/ATP) III dan International Diabetes Federation (IDF), sindrom metabolik terjadi apabila ada setidaknya tiga dari lima kondisi medis berikut: obesitas sentral, tekanan darah tinggi, peningkatan glukosa plasma puasa, kadar trigliserida serum yang tinggi, dan kadar high-density lipoprotein (HDL) yang rendah. ${ }^{4}$ Di antara penyakit-penyakit metabolik, yang paling sering terjadi adalah hipertensi dan diabetes melitus yang prevalensinya meningkat seiring dengan bertambahnya usia. ${ }^{5}$ Hipertensi merupakan faktor risiko utama dari penyakit kardiovaskular yang diketahui menjadi penyebab kematian nomor satu di Indonesia. ${ }^{6,7}$ Sedangkan diabetes melitus menempati peringkat ketiga penyebab mortalitas di Indonesia menurut WHO pada tahun $2012 .^{7}$

Seseorang yang mengalami sindrom metabolik dan tidak ditangani dengan benar akan berisiko mengalami penyakit kardiovaskular seperti penyakit jantung koroner dan stroke. ${ }^{8}$ Meningkatnya lemak viseral pada awal patofisiologi sindrom metabolik memicu peningkatan kadar lemak plasma dan produksi sitokin-sitokin inflamasi., ${ }^{9,10}$ Peningkatan produk sitokin ini dapat mengganggu interaksi insulin dengan reseptornya yang dapat menyebabkan resistensi insulin dengan manifestasi diabetes melitus. ${ }^{11}$ Peningkatan jaringan adiposa juga meningkatkan jumlah sel-sel kekebalan tubuh yang berperan dalam peradangan. Peradangan kronis berkontribusi dalam terjadinya peningkatan risiko hipertensi dan diabetes. ${ }^{12}$

Penyebab terjadinya sindrom metabolik sangat kompleks, meliputi faktor genetik dan faktor lingkungan. Faktor lingkungan yang kurang baik dapat menimbulkan sindrom metabolik. Aktivitas fisik yang rendah, gangguan tidur, kondisi pascamenopause pada wanita, merokok, dan diet tinggi karbohidrat merupakan faktor risiko sindrom metabolik. ${ }^{13,14}$ Di samping itu, sindrom metabolik kebanyakan diderita pasien yang lebih tua, gemuk, memiliki tingkat resistensi insulin, dan sering mengalami stres. ${ }^{15-17}$ Jenis pekerjaan dan status sosial ekonomi juga berhubungan dengan risiko terjadinya sindrom metabolik di mana pekerjaan menentukan aktivitas fisik dan kelas sosioekonomi berkaitan dengan pendidikan dan akses terhadap informasi. ${ }^{18-20}$

Di daerah perkotaan di Indonesia, prevalensi sindrom metabolik mencapai $28,4 \%,{ }^{21}$ sedangkan di daerah pedesaan prevalensinya adalah $18,2 \%{ }^{22}$ Keberagaman penduduk, faktor sosial ekonomi, 
mata pencaharian, pendidikan, dan pengetahuan tentang kesehatan bervariasi di setiap daerah. Heterogenitas ini mencerminkan karakteristik tertentu, terutama terkait adanya penyakitpenyakit metabolik. Mempertimbangkan adanya pengaruh lingkungan dan gaya hidup tertentu dalam terjadinya sindrom metabolik, penelitian ini bertujuan untuk mengetahui per-bedaan pada tekanan darah dan gula darah di daerah desa dan perkotaan, serta keluhan/ penyakit utama di kedua daerah tersebut. Daerah pedesaan diwakili Dusun Bantar Kulon, Desa Banguncipto, Kecamatan Sentolo, Kabupaten Kulon Progo, dan daerah perkotaan diwakili Dusun Kronggahan, Kelurahan Trihanggo, Kecamatan Gamping, Kabupaten Sleman.

\section{Metode}

Penelitian ini adalah penelitian observasional dengan teknik pengambilan data purposive sampling. Subjek yang diambil berusia di atas 18 tahun. Data diambil saat dilakukan pengabdian masyarakat pada tanggal 12 Juni 2016 di Bantar Kulon, Banguncipto, Sentolo, Kulon Progo sebagai wilayah pedesaan dan pada tanggal 23 Mei 2015 di Dusun Kronggahan, Trihanggo, Gamping, Sleman sebagai wilayah perkotaan.

Kadar glukosa puasa diukur menggunakan GCU Multi-Function Monitoring System (EasyTouch ${ }^{\circledR}$ ). Subjek diminta untuk puasa 8 jam sebelum pemeriksaan. Pengukuran tekanan darah dilakukan menggunakan sphygmomanometer raksa dan otomatis (Omron, HEM). Pengambilan data keluhan kesehatan dilakukan menggunakan metode wawancara oleh dokter untuk mengetahui keluhan/ penyakit utama yang dialami subjek.

Normalitas data diuji dengan uji KolmogorovSmirnoff, apabila data tidak normal dilakukan uji non-parametrik. Analisis data dilakukan dengan uji t untuk uji parametrik dan uji Mann-Whitney U untuk uji non-parametrik. Keluhan/ penyakit utama ditampilkan dalam tabel frekuensi. Interval kepercayaan pada penelitian ini 95\% sehingga nilai $p<0,05$ dinyatakan bermakna secara statistik.

\section{Hasil}

Secara keseluruhan, subjek penelitian berjumlah 162 orang, terdiri dari 71 orang dari Bantar Kulon (desa) dan 91 orang dari Kronggahan (kota). Sebagian besar responden berjenis kelamin lakilaki, baik di Bantar Kulon (70,4\%) maupun di Kronggahan (81,3\%). Mayoritas subjek merupakan lansia dengan rata-rata usia di atas 50 tahun pada di kedua dusun. Rerata indeks massa tubuh (IMT) di Kronggahan lebih tinggi daripada Bantar Kulon ( $p$ $<0,001)$. Karakteristik subjek, tekanan darah, dan kadar gula darah puasa subjek disajikan pada Tabel 1.

Sebanyak 24 orang $(33,8 \%)$ di Bantar Kulon mengalami hipertensi (tekanan darah sistol $\geq 140$ dan/ atau tekanan darah diastol $\geq 90$ ), sedangkan di Kronggahan mencapai 46 orang (50,5\%). Gula darah puasa (GDP) di kedua lokasi tidak berbeda bermakna ( $p=0,385$ ). Namun, persentase subjek yang memiliki GDP di atas normal ( $\geq 100 \mathrm{mg} / \mathrm{dL}$ ) lebih tinggi di Bantar Kulon, yaitu sebanyak 42,3\%.

Tabel 2 dan 3 menunjukkan keluhan atau penyakit utama di Bantar Kulon dan Kronggahan berturut-turut. Setiap subjek dapat mengalami lebih dari satu keluhan/ penyakit. Berdasarkan hasil wawancara, hipertensi merupakan penyakit yang paling banyak dialami subjek di kedua dusun dengan frekuensi sekira sepertiga penduduk, disusul oleh myalgia. Diabetes melitus berada di urutan keempat dengan persentase di bawah $10 \%$. Gambar 1 dan Gambar 2 menunjukkan kegiatan pemeriksaan kesehatan, tekanan darah, dan kadar glukosa darah puasa di Dusun Bantar Kulon dan Kronggahan.

\section{Pembahasan}

Dusun Bantar Kulon, Banguncipto, Sentolo, Kulon Progo merupakan daerah pedesaan yang terletak di Daerah Istimewa Yogyakarta bagian barat dan merupakan pintu gerbang masuk dari Provinsi Jawa Tengah ke Daerah Istimewa Yogyakarta dari arah barat. Sekira seperempat penduduk di Kelurahan Banguncipto bekerja di bidang pertanian, perikanan, dan peternakan. Sebagian 
Tabel 1. Karakteristik, tekanan darah, dan gula darah subjek dari Dusun Bantar Kulon dan Kronggahan

\begin{tabular}{|c|c|c|c|}
\hline & $\begin{array}{c}\text { Bantar Kulon } \\
(n=71)\end{array}$ & $\begin{array}{c}\begin{array}{c}\text { Kronggahan } \\
(n=91)\end{array} \\
\end{array}$ & $p$ \\
\hline Umur (tahun), rerata $\pm S B$ & $55,7 \pm 12,2$ & $50,5 \pm 12,4$ & $0,004^{1}$ \\
\hline$<35$ tahun, $\mathrm{n}(\%)$ & $3(4,2)$ & $8(8,8)$ & - \\
\hline 35-49 tahun, n (\%) & $17(23,9)$ & $39(42,9)$ & - \\
\hline 50-64 tahun, $\mathrm{n}(\%)$ & $31(43,7)$ & $31(34,1)$ & - \\
\hline$\geq 65$ tahun, $\mathrm{n}(\%)$ & $20(28,2)$ & $13(14,3)$ & - \\
\hline \multicolumn{4}{|l|}{ Jenis kelamin } \\
\hline Laki-laki, n (\%) & $21(29,6)$ & $17(18,7)$ & - \\
\hline Perempuan, n (\%) & $50(70,4)$ & $74(81,3)$ & - \\
\hline Tinggi badan $(\mathrm{cm})$, rerata $\pm \mathrm{SB}$ & $154,6 \pm 8,4$ & $151,9 \pm 6,4$ & $0,027^{2}$ \\
\hline Berat badan $(\mathrm{kg})$, rerata $\pm \mathrm{SB}$ & $55,3 \pm 11,4$ & $59,8 \pm 12,5$ & $0,020^{2}$ \\
\hline $\mathrm{IMT}\left(\mathrm{kg} / \mathrm{m}^{2}\right)$, rerata $\pm \mathrm{SB}$ & $23,1 \pm 4,0$ & $25,8 \pm 5,0$ & $<0,001^{1}$ \\
\hline TD sistol $(\mathrm{mmHg})$, rerata $\pm \mathrm{SB}$ & $131,6 \pm 20,9$ & $136,3 \pm 22,9$ & $0,159^{1}$ \\
\hline TD diastol $(\mathrm{mmHg})$, rerata $\pm \mathrm{SB}$ & $81,6 \pm 11,4$ & $86,4 \pm 11,5$ & $0,007^{1}$ \\
\hline \multicolumn{4}{|l|}{ Kategori TD } \\
\hline Normal, n (\%) & $47(66,2)$ & $45(49,5)$ & - \\
\hline Hipertensi, n (\%) & $24(33,8)$ & $46(50,5)$ & - \\
\hline $\mathrm{GDP}(\mathrm{mg} / \mathrm{dL})$, rerata $\pm \mathrm{SB}$ & $101,6 \pm 35,9$ & $101,1 \pm 38,5$ & $0,385^{1}$ \\
\hline$<100$ mg/dL, n (\%) & $41(57,7)$ & $67(73,6)$ & - \\
\hline$\geq 100 \mathrm{mg} / \mathrm{dL}, \mathrm{n}(\%)$ & $30(42,3)$ & $24(26,4)$ & - \\
\hline
\end{tabular}

SB: simpangan baku, IMT: indeks massa tubuh, TD: tekanan darah. Hasil uji statistik dinyatakan bermakna apabila $p$ $<0,05$. ${ }^{1}$ Hasil uji Mann-Whitney U. ${ }^{2}$ Hasil independent $t$-test

Tabel 2. Keluhan/ penyakit utama pada penduduk Dusun Bantar Kulon $(n=71)$

\begin{tabular}{lc}
\hline Keluhan/ penyakit & $\mathbf{n}(\%)$ \\
\hline Hipertensi & $23(32,4)$ \\
Myalgia & $19(26,8)$ \\
Sefalgia & $8(11,3)$ \\
Diabetes melitus & $4(5,6)$
\end{tabular}

Persentase adalah $\mathrm{n}$ subjek yang mengalami keluhan/ penyakit per $\mathrm{n}$ total subjek dikalikan $100 \%$.

besar penduduk bekerja sebagai petani, dan hanya sebagian kecil yang bekerja sebagai pegawai negeri sipil (PNS) dan wiraswasta sehingga di dalam kehidupan sehari-hari lebih banyak menggunakan aktivitas fisik. ${ }^{23}$ Secara sosial ekonomi, Dusun Bantar Kulon merupakan daerah dengan penghasilan ratarata menengah ke bawah.

Dusun Kronggahan merupakan sebuah dusun di wilayah desa Trihanggo yang terletak di
Tabel 3. Keluhan/ penyakit utama pada penduduk Dusun Kronggahan $(n=91)$

\begin{tabular}{lc}
\hline Keluhan/ penyakit & $\mathbf{n}(\%)$ \\
\hline Hipertensi & $30(33,0)$ \\
Myalgia & $10(11,0)$ \\
Osteoarthritis & $8(8,8)$ \\
Diabetes melitus & $7(7,7)$ \\
\hline Persentase adalah $\mathrm{n}$ subjek yang mengalami keluhan/ \\
penyakit per $\mathrm{n}$ total subjek dikalikan $100 \%$.
\end{tabular}

Kecamatan Gamping, Sleman, Daerah Istimewa Yogyakarta. Kawasan ini menjadi salah satu kawasan hunian yang dekat dengan Kota Yogyakarta. Secara geografis, desa Trihanggo mempunyai letak yang strategis dengan mayoritas penduduk bekerja sebagai PNS dan wiraswasta, dan sebagian kecil sebagai buruh tani. ${ }^{24}$ Secara sosial ekonomi, Dusun Kronggahan merupakan daerah dengan kategori menengah ke atas, meskipun kondisi ini tidak merata. 


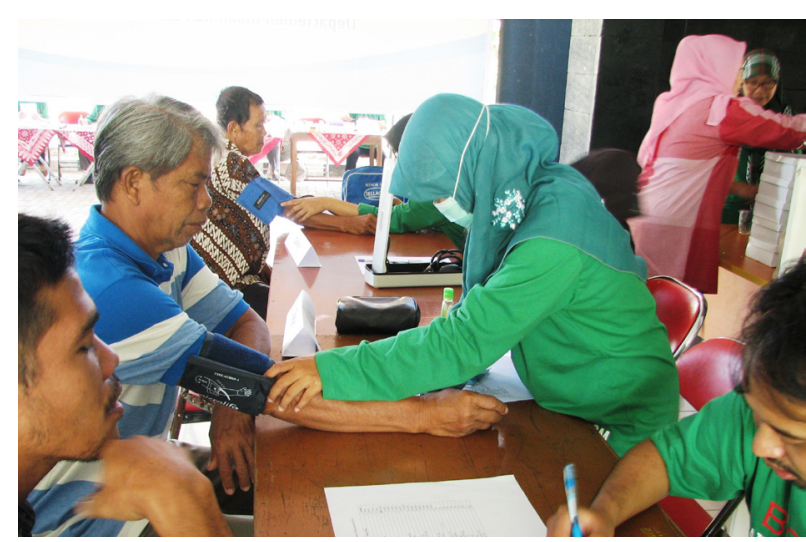

(a)

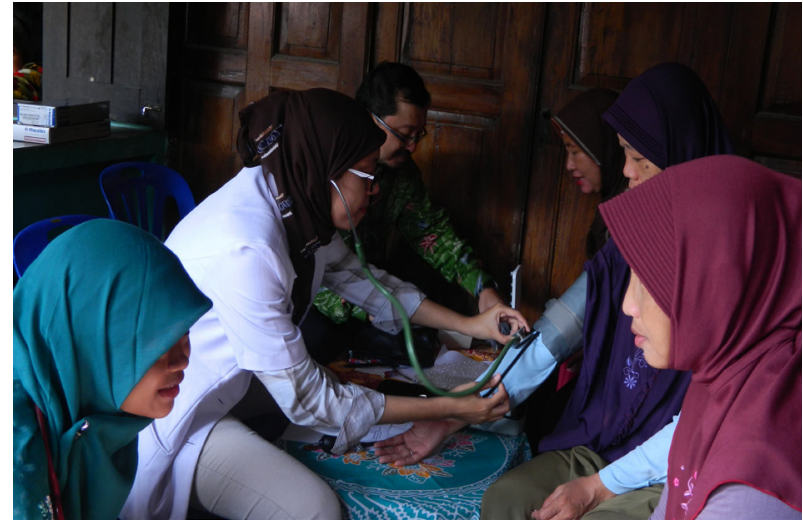

(b)

Gambar 1. Pemeriksaan kesehatan dan tekanan darah di Dusun Bantar Kulon (a) dan Kronggahan (b)

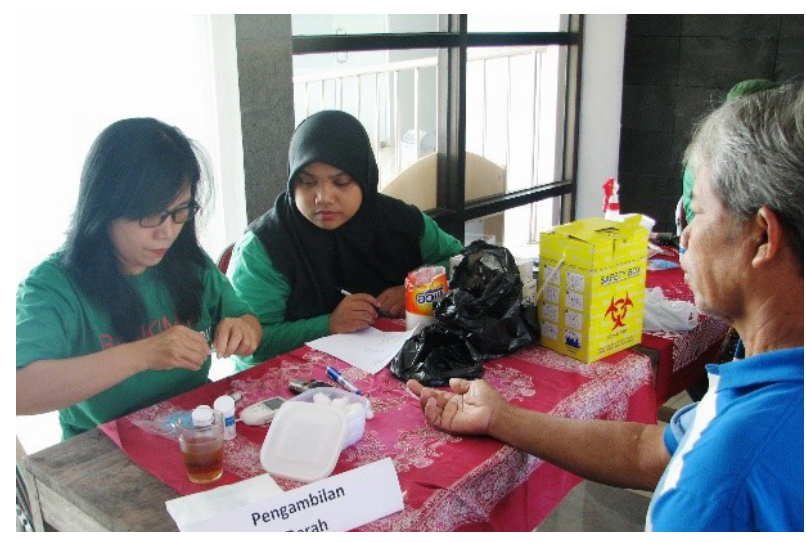

(a)

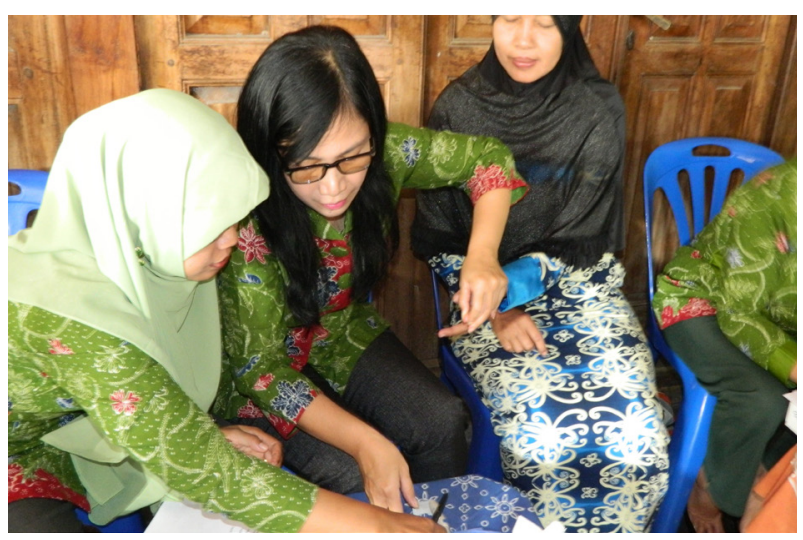

(b)

Gambar 2. Pengambilan darah untuk pemeriksaan kadar glukosa darah di Dusun Bantar Kulon (a) dan Kronggahan (b)

Dari pengukuran antropometri, rerata berat badan berbeda bermakna antara kedua dusun $(p=$ $0,02)$ dan rerata IMT secara bermakna lebih tinggi di Dusun Kronggahan $(p<0,001)$. Namun, karena lebih dari $70 \%$ subjek di Bantar Kulon dan sekitar setengah dari subjek di Kronggahan adalah lansia, penggunaan cut-off IMT dewasa kurang sensitif dibandingkan lingkar perut dalam memprediksi risiko sindrom metabolik. ${ }^{25}$

Sindrom metabolik merupakan kumpulan dari beragam gangguan metabolisme penyebab berbagai penyakit. Kadar glukosa darah tinggi sering berkembang menjadi penyakit diabetes melitus tipe 2. Menurut International Diabetes Federation (IDF), salah satu faktor risiko sindrom metabolik adalah ketika kadar glukosa darah puasa $\geq 100 \mathrm{mg} / \mathrm{dL}^{26}$ Pada pemeriksaan darah, 40,3\% subjek dari Bantar
Kulon memiliki GDP $\geq 100 \mathrm{mg} / \mathrm{dL}$, sedangkan di daerah kota persentasenya hanya $26,4 \%$. Kemungkinan hal ini disebabkan oleh rendahnya tingkat ekonomi dan tingkat pendidikan penduduk pedesaan dibanding penduduk perkotaan. Selain itu, faktor usia juga dapat berperan. Individu dengan usia lanjut lebih berpotensi diklasifikasikan memiliki kadar glukosa abnormal menurut cut-off yang ada dibandingkan dewasa muda. ${ }^{27}$ Rerata usia subjek Bantar Kulon lebih tinggi daripada di Kronggahan dan sebanyak 71,9\% subjek dari Bantar Kulon berusia $\geq 50$ tahun.

Faktor risiko sindrom metabolik yang lain adalah hipertensi. Menurut the Seventh Report of the Joint National Committee (JNC 7) on Prevention, Detection, Evaluation, and Treatment of High Blood Pressure, hipertensi didefinisikan sebagai tekanan 
darah sistol di atas $140 \mathrm{mmHg}$ dan/ atau tekanan darah diastol di atas $90 \mathrm{mmHg} .{ }^{28}$ Tekanan darah tinggi merupakan kondisi ketika tekanan darah di arteri terlalu tinggi. Rerata tekanan darah baik sistolik maupun diastolik di Kronggahan lebih tinggi dari Bantar Kulon dengan 50,5\% subjek di Kronggahan masuk ke dalam kategori hipertensi. Salah satu faktor risiko hipertensi adalah stres. ${ }^{29}$ Tingginya hipertensi di wilayah perkotaan dapat disebabkan oleh besarnya stressor di kota dibandingkan di desa ${ }^{30}$ Gaya hidup dan tekanan sosial orang kota berbeda dengan orang-orang desa yang lebih merasa tenteram hidup di desa. ${ }^{31}$

Penelitian terdahulu menyebutkan bahwa sindrom metabolik sangat erat kaitannya dengan metabolisme individu atau bagaimana tubuh memproses makanan. Secara normal, makanan diserap tubuh ke aliran darah dalam bentuk glukosa dan substansi dasar lainnya. Ketika kadar glukosa darah meningkat, pankreas melepaskan hormon insulin untuk menginduksi pengambilan glukosa oleh sel untuk digunakan sebagai energi. ${ }^{32}$ Pada beberapa orang, pola hidup dan faktor genetik tertentu dapat menyebabkan terjadinya resistensi insulin sehingga terjadi peningkatan glukosa darah. ${ }^{15}$

Berdasarkan wawancara, hipertensi menempati urutan paling atas keluhan/ penyakit utama baik di Bantar Kulon maupun Kronggahan dengan persentase yang tidak jauh berbeda di kedua daerah tersebut $(32,4 \%$ vs 33,0\%). Meskipun demikian, hasil pemeriksaan di Kronggahan menunjukkan bahwa tekanan darah pada 50,5\% subjek masuk ke dalam kategori hipertensi. Hal ini mengindikasikan bahwa deteksi hipertensi di wilayah tersebut kurang.

Keluhan/ penyakit utama terbanyak kedua adalah myalgia. Presentase myalgia subjek di Bantar Kulon lebih tinggi daripada di Kronggahan (26,8\% vs $11,0 \%)$. Hal ini dapat disebabkan karena persentase subjek dengan usia lanjut lebih banyak di Bantar Kulon serta mata pencaharian penduduk desa yang mayoritas petani. Penurunan massa otot pada lansia dapat menyebabkan gangguan seperti nyeri otot atau myalgia, ${ }^{33}$ sedangkan mata pencaharian petani yang membutuhkan gerakan repetitif dan monoton serta beban kerja yang berat dapat menyebabkan gejala muskuloskeletal pada area tertentu seperti nyeri punggung dan ekstrimitas. $^{34,35}$

Jumlah penderita diabetes mellitus pada daerah perkotaan lebih tinggi dibanding di daerah pedesaan. Namun, jumlah subjek yang memiliki GDP $>100 \mathrm{mg} / \mathrm{dL}$ pada saat pemeriksaan jauh lebih banyak di Bantar Kulon. Hal ini dapat disebabkan karena kurangnya kesadaran masyarakat desa akan diabetes karena kesenjangan informasi dan terbatasnya akses pelayanan kesehatan di desa. Menurut Soewondo, lebih dari $70 \%$ kasus diabetes di Indonesia tidak terdiagnosis pada tahun 2007. ${ }^{36}$

Persentase subjek yang mengeluhkan hipertensi di Bantar Kulon maupun Kronggahan adalah $32,4 \%$ dan $33,0 \%$ berturut-turut. Angka ini mendekati prevalensi hipertensi nasional pada orang dewasa yaitu $33,4 \% .{ }^{37}$ Sementara itu, prevalensi diabetes melitus di Indonesia pada tahun 2013 adalah 5,6\% dan diprediksi mencapai 6,7\% pada $2035 .{ }^{38}$ Jumlah subjek yang telah didiagnosis diabetes melitus di Bantar Kulon sebanyak 4 orang (5,6\%) dan di Kronggahan sebanyak 7 orang $(7,7 \%)$. Hal ini menunjukkan bahwa prevalensi di desa masih berkisar pada prevalensi nasional, sedangkan prevalensi diabetes subjek di kota berada di atas prevalensi nasional tersebut.

\section{Kesimpulan}

Kadar glukosa darah puasa subjek tidak berbeda secara bermakna antara desa (Dusun Bantar Kulon) dan kota (Kronggahan). Namun, persentase subjek yang memiliki faktor risiko sindrom metabolik GDP $\geq 100 \mathrm{mg} / \mathrm{dL}$ lebih tinggi di Bantar Kulon. Rerata tekanan darah diastol dan persentase hipertensi berdasarkan pemeriksaan lebih tinggi di daerah perkotaan daripada desa. Baik di desa maupun di kota, hipertensi menempati urutan pertama keluhan/ penyakit utama, disusul oleh myalgia.

Penelitian ini memberikan gambaran perbandingan faktor risiko sindrom metabolik berupa GDP di atas normal dan hipertensi, serta 
keluhan/ penyakit utama pada wilayah pedesaan dan perkotaan di Yogyakarta. Penelitian selanjutnya sebaiknya mencakup kegiatan edukasi terkait hipertensi dan diabetes melitus yang termasuk penyakit utama di kedua wilayah. Selain itu, penelitian selanjutnya sebaiknya mencakup analisis faktor risiko lain yang berperan dalam terjadinya sindrom metabolik seperti asupan makan dan tingkat stres subjek.

\section{Ucapan terima kasih}

Kami mengucapkan terima kasih kepada Fakultas Kedokteran, Kesehatan Masyarakat dan Keperawatan, Universitas Gadjah Mada yang sudah memberikan dana melalui hibah pengabdian kepada masyarakat. Terima kasih juga kami ucapkan kepada segenap pihak serta warga Bantar Kulon dan Kronggahan yang telah bekerja sama demi terlaksananya pengabdian kepada masyarakat dan penelitian ini.

\section{Daftar pustaka}

1. Scholze J, Alegria E, Ferri C, Langham S, Stevens $\mathrm{W}$, Jeffries $\mathrm{D}$, et al. Epidemiological and economic burden of metabolic syndrome and its consequences in patients with hypertension in Germany, Spain and Italy; a prevalence-based model. BMC Public Health. 2010;10(1):529.

2. Nolan PB, Carrick-Ranson G, Stinear JW, Reading SA, Dalleck LC. Prevalence of metabolic syndrome and metabolic syndrome components in young adults: A pooled analysis. Prev Med reports. 2017;7:211-5.

3. Suhaema $S$, Masthalina H. Pola konsumsi dengan terjadinya sindrom metabolik. Jurnal Kesehatan Masyarakat Nasional. 2015;9(4):340.

4. Kaur J. A comprehensive review on metabolic syndrome. Cardiol Res Pract. 2014;2014:943162.

5. World Health Organization. Chronic Respiratory Diseases and Arthritis Team.? Screening for type 2 diabetes : report of a World Health Organization and International Diabetes Federation meeting [Internet]. Geneva : World
Health Organization; 2003 [cited 2018 Aug 27]. Available from: http://www.who.int/iris/ handle/10665/68614

6. Kjeldsen SE. Hypertension and cardiovascular risk: General aspects. Pharmacol Res. 2018;129:95-9.

7. Centers for Disease Control and Prevention. CDC Global Health - Indonesia [Internet]. Centers for Disease Control and Prevention; 2016 [cited 2018 October 27]. Available from: https://www.cdc.gov/globalhealth/countries/ Indonesia/

8. Levine TB, Levine AB. Metabolic syndrome and cardiovascular disease. 12th ed. UK: WileyBlackwell; 2012.

9. Makki K, Froguel P, Wolowczuk I. Adipose tissue in obesity-related inflammation and insulin resistance: cells, cytokines, and chemokines. ISRN Inflamm; 2013:139239.

10. Hwang Y-C, Fujimoto WY, Hayashi T, Kahn $\mathrm{SE}$, Leonetti DL, Boyko EJ. Increased Visceral Adipose Tissue Is an Independent Predictor for Future Development of Atherogenic Dyslipidemia. J Clin Endocrinol Metab. 2016;101(2):678-85.

11. Boucher J, Kleinridders A, Kahn CR. Insulin receptor signaling in normal and insulinresistant states. Cold Spring Harb Perspect Biol. 2014;6(1):a009191.

12. Masharani U. Diabetes mellitus and hyperglycemia. In: Tierney LM, McPhee SJ, Papadakis MA, editors. Current Medical Diagnosis and Therapy (CMDT). USA: McGraw Hill; 2005. Chapter 27

13. Power V. Diabetes mellitus. In: Wonsiewicz $M$, Ramos $M$, editors. Harrison's principles of internal medicine. 15th ed. USA: The McGrawHill Company; 2005. Chapter 333

14. Porter WH, Moyer TP. Tietz fundamentals of clinical chemistry. 5th ed. USA: WB Saunders Company; 2000.

15. Mayans L. Metabolic syndrome: insulin resistance and prediabetes. FP Essent. 2015;435:11-6.

16. Rosenbaum S, Stubbs B, Ward PB, Steel Z, 
Lederman $\mathrm{O}$, Vancampfort $\mathrm{D}$. The prevalence and risk of metabolic syndrome and its components among people with posttraumatic stress disorder: a systematic review and metaanalysis. Metabolism. 2015;64(8):926-33.

17. Dominguez LJ, Barbagallo M. The biology of the metabolic syndrome and aging. Curr Opin Clin Nutr Metab Care. 2016;19(1):5-11.

18. Kim JY, Kim SH, Cho YJ. Socioeconomic status in association with metabolic syndrome and coronary heart disease risk. Korean J Fam Med. 2013;34(2):131-8.

19. Strauß $M$, Foshag $P$, Przybylek $B$, Horlitz $M$, Lucia A, Sanchis-Gomar F, et al. Occupation and metabolic syndrome: is there correlation? A cross sectional study in different work activity occupations of German firefighters and office workers. Diabetol Metab Syndr. 2016;8(1):57.

20. Mirowsky J, Catherine, ER. Education, social status, and health. New York: Routledge; 2003.

21. Ranasinghe $P$, Mathangasinghe $Y$, Jayawardena $R$, Hills AP, Misra A. Prevalence and trends of metabolic syndrome among adults in the asiapacific region: a systematic review. BMC Public Health. 2017;17(1):101.

22. Dwipayana MP, Suastika K, Saraswati I, Gotera W, Budhiarta A, Sutanegara, et al. Prevalensi sindroma metabolik pada populasi penduduk bali, indonesia. Jurnal Penyakit Dalam. 2011;12(1):1-5.

23. Biro Tata Pemerintahan Setda DIY. Jumlah penduduk menurut jenis pekerjaan di Kecamatan Sentolo, Kabupaten Kulonprogo, DI Yogyakarta semester I 2014 [Internet]. [cited 2018 October 27]. Available from: http://kependudukan.jogjaprov.go.id/sarkan= pekerjaan \& prop $=34 \& k a b=01 \& k e c=06$

24. Biro Tata Pemerintahan Setda DIY. Jumlah Penduduk Menurut Jenis Pekerjaan di Kecamatan Gamping, Kabupaten Sleman, DI Yogyakarta Semester I 2014 [Internet]. [cited 2018 October 27]. Available from: http:// kependudukan.jogjaprov.go.id/olah.

25. Oliveira CC de, Costa ED da, Roriz AKC, Ramos LB, Gomes Neto M, Oliveira CC de, et al. Predictors of Metabolic Syndrome in the Elderly: A Review. Int I Cardiovasc Sci. 2017;30(4):343-53.

26. International Diabetes Federation. The IDF consensus worldwide definition of the metabolic syndrome [Internet]. 2006 [cited 2018 October 27]. Available from: https://www. idf.org/e-library/consensus-statements/60idfconsensus-worldwide-definitionof-themetabolic-syndrome

27. Kalyani RR, Egan JM. Diabetes and altered glucose metabolism with aging. Endocrinol Metab Clin North Am. 2013;42(2):333-47.

28. National Heart Lung and Blood Institute. The Seventh Report of the Joint National Committee on Prevention, Detection, Evaluation, and Treatment of High Blood Pressure (JNC 7) [Internet]. National Heart, Lung, and Blood Institute (NHLBI); 2003 [cited 2018 October 27]. Available from: https://www.nhlbi.nih. gov/health-topics/seventh-report-of-jointnational-committee-on-prevention-detectionevaluation-and-treatment-high-bloodpressure

29. Pickering TG. Mental stress as a causal factor in the development of hypertension and cardiovascular disease. Curr Hypertens Rep. 2001;3(3):249-54.

30. Vassos E, Agerbo E, Mors O, Pedersen CB. Urban-rural differences in incidence rates of psychiatric disorders in Denmark. $\mathrm{Br} J$ Psychiatry. 2016;208(05):435-40.

31. Lederbogen $F$, Kirsch $P$, Haddad L, Streit F, Tost $\mathrm{H}$, Schuch $\mathrm{P}$, et al. City living and urban upbringing affect neural social stress processing in humans. Nature. 2011;474(7352):498-501.

32. Guo S. Insulin signaling, resistance, and the metabolic syndrome: Insights from mouse models into disease mechanisms. J Endocrinol. 2014;220(2):T1-23.

33. Sumardiyono S, Lowa NW, Azzam AM, Huda $\mathrm{KN}$, Nurfauziah N. Kejadian myalgia pada lansia pasien rawat jalan. Jurnal Riset Sains dan Teknologi. 2017;1(2):59. 
34. Holmberg S, Thelin A, Stiernstrom E, Svardsudd $K$. The impact of physical work exposure on musculoskeletal symptoms among farmers and rural non-farmers. Ann Agric Environ Med. 2003;10(2):179-84.

35. Osborne A, Blake C, Fullen BM, Meredith D, Phelan J, McNamara J, et al. Prevalence of musculoskeletal disorders among farmers: A systematic review. Am J Ind Med. 2012;55(2):143-58.

36. Soewondo P, Ferrario A, Tahapary D. Challenges in diabetes management in Indonesia: a literature review. Global Health. 2013;9(1):63.
37. Peltzer K, Pengpid S. The prevalence and social determinants of hypertension among adults in indonesia: A cross-sectional population-based national survey. Int J Hypertens. 2018;2018:19.

38. Guariguata L, Whiting DR, Hambleton I, Beagley J, Linnenkamp U, Shaw JE. Global estimates of diabetes prevalence for 2013 and projections for 2035. Diabetes Res Clin Pract. 2014;103(2):137-49. 